\title{
Water workgroup recommends new salinity guidelines for regulatory agencies
}

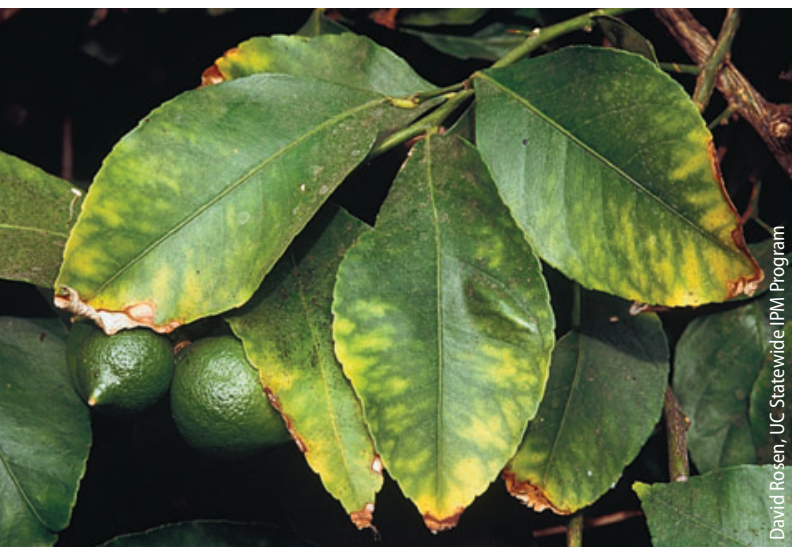

Excess salinity in irrigation water or soil can cause necrosis in citrus leaves.

L eaching requirement guidelines published in the 1980s to help growers manage salt buildup in crop fields now need retooling, say workgroup members appointed by the UC Center for Water Resources. Workgroup chair John Letey, former director of the center, says the group found that current guidelines overestimate the leaching requirement and the negative effects of salinity.

Rather than issuing new recommendations for growers, however, the workgroup has proposed new guidelines for agencies that regulate the water quality of irrigation sources (table 1). They have shared them with California Agriculture, but plan no other formal report.

Salinity is a sensitive issue for agriculture. If salts in irrigation water (such as chloride, sulfate, bicarbonate, sodium, calcium and magnesium) build up in the root zone, plant growth and yields can be affected. In the worst cases, soils become too saline for agricultural use. Leaching is application of extra water to carry salts below the root zone. The leaching requirement (LR) guidelines specify how much extra water (the leaching fraction, LF) should be applied to maintain maximum crop yields.

\section{Significance of LR guidelines}

Today, the LR guidelines are more significant than when they were published: If less water needs to be applied for leaching, as the workgroup suggests, groundwater might be more easily protected from pesticides and nitrates carried in drainage water. And if water with elevated salinity levels can be used for irrigation, more water might be available to growers and for competing urban and environmental uses.

Although now perhaps outdated, the LR guidelines were originally a formidable research undertaking.

"They have been published in textbooks and taught in class and are generally accepted as

Members of the UC Center for Water Resources leaching fraction workgroup are: Christopher Amrhein, Dennis Corwin, Stephen Grattan, Glenn Hoffman, Jan Hopmans, John Letey, J.D. Oster, Donald Suarez and Laosheng Wu. being valid and useful," Letey says. "I am not critical of them because they were the best that could be done at the time, and they have been useful. However, we can do better presently."

The original guidelines were calculated from steady-state analysis.
In an Agricultural Water Management article (February 2011), the workgroup explained the problem:

"Mathematically, a steady-state flow analysis does not include a time variable ... Steady-state specifies that applied irrigation water is continuously flowing downwards at a constant rate, irrespective of irrigation frequency ... that evapotranspiration is constant over the growing season. Consequently, steady-state solutions assume that the salt concentration of the soil solution at any point in the soil profile is constant at all times. None of these is real."

There are several transient-state models available that can be used to assess salinity management. Using a transient-state model, a user enters real-time data, including the time and amount of each irrigation, the salinity of the irrigation water, the current evapotranspiration rate for the crop, and so on. The model then creates simulations of dynamic interactions in the root zone and continuously updates the conditions, such as soil-water and salinity, that can affect crop yield.

\section{Recommendation to regulators}

The workgroup has no plans to issue new LR guidelines for growers; however, it is recommending new guidelines for regulatory agencies, such as the California State Water Resources Control Board, that manage the quality standards for bodies of water that supply irrigation to growers, such as the San Joaquin River. The new guidelines are based on steady-state analysis but with two important modifications: They use a water-uptake-weighted average of salinity in the root zone instead of a linear average, and they take rainfall into account (table 1).

\begin{tabular}{|c|c|c|c|c|c|c|c|}
\hline \multirow{2}{*}{$\begin{array}{l}\text { Leaching } \\
\text { fraction }\end{array}$} & \multicolumn{7}{|c|}{ Annual rainfall to total water applied } \\
\hline & $0 \%$ & $10 \%$ & $15 \%$ & $20 \%$ & $25 \%$ & $30 \%$ & $35 \%$ \\
\hline & \multicolumn{7}{|c|}{$\ldots \ldots \ldots \ldots \ldots$ decisiemens per meter. } \\
\hline 0.05 & 0.63 & 0.70 & 0.74 & 0.79 & 0.84 & 0.90 & 0.97 \\
\hline 0.10 & 0.78 & 0.86 & $0.91 \dagger$ & 0.98 & 1.04 & 1.11 & 1.20 \\
\hline 0.15 & 0.90 & 1.00 & 1.05 & 1.12 & 1.20 & 1.28 & 1.38 \\
\hline 0.20 & 1.00 & 1.11 & 1.17 & 1.25 & 1.33 & 1.43 & 1.54 \\
\hline 0.25 & 1.06 & 1.17 & 1.25 & 1.32 & 1.41 & 1.51 & 1.63 \\
\hline 0.30 & 1.18 & 1.31 & 1.39 & 1.48 & 1.57 & 1.68 & 1.81 \\
\hline
\end{tabular}


First, a leaching fraction is chosen, based on the extra water that must be applied to avoid yield loss in the most sensitive crop grown by area farmers; then rainfall is calculated for the area. Using these two figures, the maximum salinity level of the irrigation source can be read off the table. The new guidelines mean that regulators may accept higher salinity readings at any particular point in a river, allowing somewhat more saline discharge waters from growers or other users (such as cities) upstream.

If adopted, the workgroup's recommendations will potentially result in more saline water used in agriculture. Any changes in salinity recommendations are likely to be met with concerns about future water supplies, long-term damage to soils and other issues.

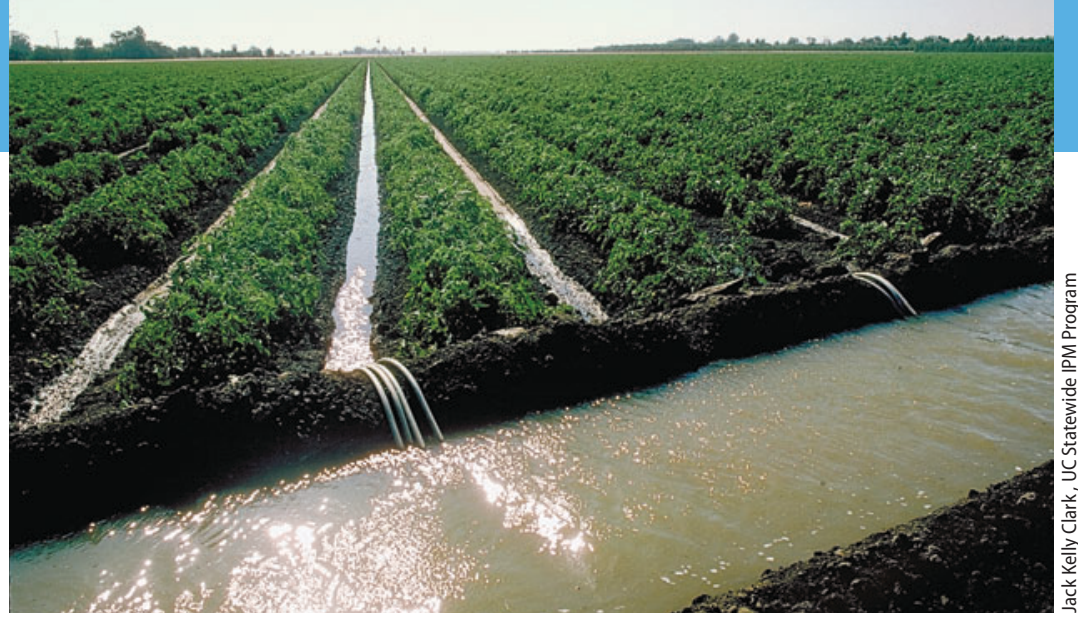

New irrigation recommendations, based on more up-to-date models, use real-time data on rainfall, evapotranspiration rates and other factors to ensure that irrigation water does not damage crops such as, above, tomatoes.

Letey is expecting some resistance to the workgroup's recommendations.

"Oh, absolutely, I expect it," he says. "People will say 'You have to convince me', and that's as it should be. But if we can get by with less water, that's a good thing." - - Hazel White and Janet White

\section{Tree-killing pathogen traced back to California}

enetic detective work by an international group

$\mathcal{J}$ of researchers may have solved a decades-long mystery of the source of a devastating tree-killing fungus that has hit six of the world's seven continents.

In a Sept. 1 Phytopathology study, California emerged as the top suspect for the pathogen, Seiridium cardinale, that is the cause of cypress canker disease. $S$. cardinale was first identified as causing the disease in California's San Joaquin Valley in 1928. The fungus has made its way since to Europe, Asia, New Zealand, Australia, South America and Africa. In many regions, it has infected and killed up to $95 \%$ of iconic native trees in the cypress family, including junipers

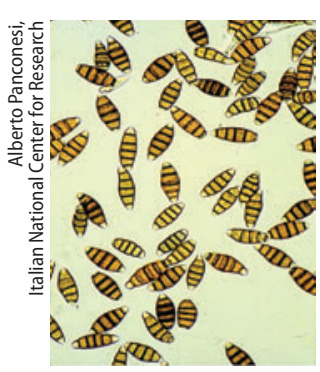

An optical microscope image shows Seiridium cardinale, the fungal pathogen responsible for a global pandemic of cypress canker disease. and some cedars.

The researchers used DNA fingerprinting techniques to analyze 96 S. cardinale isolates of diseased tree samples from seven Mediterranean countries, eight California counties, Chile and New Zealand. The paper reports that strains of the pathogen with identical DNA profiles were found hundreds to thousands of miles apart, an indication that humans are moving the pathogen, most likely through the trade of infected plants.
"When Monterey

cypress trees are planted in Monterey or along the coast, they are resistant to the disease," said Matteo Garbelotto, UC Cooperative Extension specialist, Berkeley, and an author of the study. "That suggests that in coastal areas, the environment is unfavorable for development of infections, despite the pathogen having been in California for a long time. The pathogen emerges when we place the tree in a foreign environment."

Garbelotto said that chemical treatments for cypress canker disease may become available in the near future, but they are costly and their effects on the environment are not clear so prevention is preferable.

The fungus kills a tree by entering through cracks in its bark, producing toxins that wreak havoc with its flow of sap and choke off its supply of water and nutrients. The disease has left an indelible mark throughout southern Europe.

For more info, go to: http://newscenter.berkeley.edu/ 2011/09/01/cypress-canker-pathogen-traced-to-california. - Sarah Yang

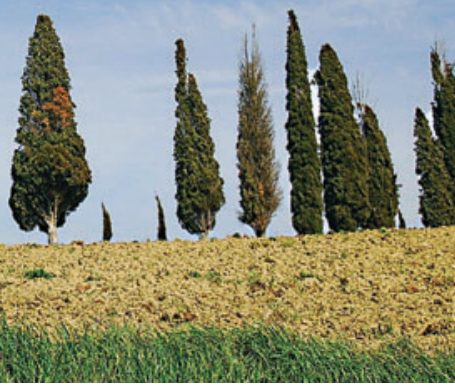

Italian cypress trees near Siena, in Italy's Tuscany region, show symptoms of cypress canker disease. Researchers have traced the origin of the pathogen responsible for the disease back to California. 